\title{
Coronary artery calibre after direct intra-arterial infusion of epoprostenol (prostacyclin)
}

\author{
J WILSON, * N P SILVERTON, * MW BAIG, * E J PERRINS, * D R SMITH, * \\ J A DAVIES, C R M PRENTICE \\ From the University Department of Medicine and *Department of Cardiology, General Infirmary, Leeds
}

SUMMARY Because epoprostenol (prostacyclin) is a prostaglandin that causes vasodilatation and inhibits platelet function it may be of benefit during coronary artery angioplasty. The safety and capacity of intracoronary epoprostenol to dilate coronary arteries were assessed in 16 patients undergoing routine coronary angiography. The view that best displayed the left epicardial coronary arteries was selected as a control for each patient. Intracoronary epoprostenol was then given and the angiogram was repeated in the chosen view. The procedure was repeated twice: once with a higher dose of epoprostenol and once after intracoronary isosorbide dinitrate. Angiograms were coded and analysed by an observer who was unaware of the treatment. The calibre of the arteries was measured from traced projections of the angiograms. The blood pressure, heart rate, and electrocardiogram were recorded throughout. The first two patients were given epoprostenol infusions of 2.5 and $5.0 \mathrm{ng} / \mathrm{kg}$ per minute to assess safety, and there were no untoward reactions. The next ten patients had epoprostenol infusions of 5.0 and $7.5 \mathrm{ng} / \mathrm{kg}$ per minute followed by intracoronary isosorbide dinitrate. No haemodynamic disturbances occurred and coronary luminal calibre did not change with epoprostenol (mean (SD) luminal diameter: $2.85(0.62) \mathrm{mm}$ control, $2.80(0.61) \mathrm{mm}$ at $5.0 \mathrm{ng} / \mathrm{kg}$, and $2.80(0.54) \mathrm{mm}$ at $7.5 \mathrm{ng} / \mathrm{kg})$, but it did increase significantly with isosorbide dinitrate (to $3 \cdot 17(0.36) \mathrm{mm}$ ). The last four patients had epoprostenol infusions of 7.5 and $10 \mathrm{ng} / \mathrm{kg}$ followed by intracoronary isosorbide dinitrate and two of them became hypotensive (one after epoprostenol and one after isosorbide dinitrate). Coronary luminal calibre did not change significantly $(3.5(0.45) \mathrm{mm}$ control, $2.96(0.81) \mathrm{mm}$ at $7.5 \mathrm{ng} / \mathrm{kg}, 3.45(0.96)$ $\mathrm{mm}$ at $10 \mathrm{ng} / \mathrm{kg}$, and $3.20(0.61) \mathrm{mm}$ with isosorbide dinitrate). Eight patients developed tall $\mathrm{T}$ waves on the electrocardiogram during epoprostenol infusion but none had arrhythmias.

The results indicate that clinically tolerable doses of intracoronary epoprostenol do not significantly dilate the epicardial coronary arteries. This route of administration is therefore unlikely to be of use during coronary angioplasty, although the antiplatelet action of intravenous epoprostenol might help to prevent restenosis.

Prostacyclin is a naturally occurring prostaglandin $\left(\mathrm{PGI}_{2}\right)$ synthesised by endothelial cells that has profound inhibitory effects on platelet aggregation. ${ }^{1}$ It is also a potent vasodilator and it has been used as a therapeutic agent (epoprostenol) to treat atherosclerotic peripheral vascular disease ${ }^{2}$ and pulmonary hypertension. ${ }^{3}$ Epoprostenol may be useful during and after transluminal coronary angioplasty because both coronary artery dilatation and inhibition of

Requests for reprints to Dr J Wilson, Department of Medicine, The Martin Wing, Leeds General Infirmary, Leeds LS1 3EX.

Accepted for publication 23 June 1988 platelet aggregation may be of benefit during this procedure. Epoprostenol dilated canine coronary arteries, ${ }^{4}$ and intracoronary infusions in man seem to be safe, ${ }^{5}$ but the effects on the diameter of human coronary arteries are not known. We have studied the effect of intracoronary epoprostenol on human coronary arteries.

\section{Patients and methods}

\section{PATIENTS}

We studied 16 patients (13 men and three women; mean age 52.7) undergoing routine coronary angiography. Patients were admitted 48 hours before 
the study so that all medication could be stopped. Patients who had attacks of angina were treated with sublingual glyceryl trinitrate. Patients gave their informed consent and the study was approved by the Leeds Western District Research Ethics Committee.

\section{CORONARY ANGIOGRAPHY}

Angiography of the left ventricle and coronary arteries was performed from the femoral approach. The images were obtained with a dedicated Phillips angiographic system ( 9 inch by 5 inch) and they were recorded on Kodak CFE or RAR film at 30 frames per second with an Arritechno camera. All patients were given sodium heparin ( $1500 \mathrm{IU}$ ) via the catheter before angiography. Non-ionic contrast medium (iopamidol 370) was used in each case. Video recordings of the standard $x$ ray projections were reviewed and the projection most clearly displaying the proximal parts of the left coronary artery was selected. Heart rate and systemic arterial blood pressure were recorded continuously throughout the procedure, and after a minimum of five minutes' equilibrium the left coronary angiogram was recorded in the chosen projection. The film was marked with a two letter code chosen by the radiographer. After the return of heart rate and blood pressure to control values, the first infusion of epoprostenol $(50 \mathrm{ml})$ was delivered via the left coronary angiographic catheter at $50 \mathrm{ml} /$ min. One minute after the infusion, the coronary angiogram was repeated under identical conditions to the control injection. The film was again marked with a double letter code. After a further five minutes, the second infusion of epoprostenol $(50 \mathrm{ml})$ was administered and the coronary angiogram was repeated one minute later. The film recording the cumulative effect of both doses was marked with a third code. The final infusion consisted of $100 \mu \mathrm{g}$ of isosorbide dinitrate in $20 \mathrm{ml}$ of $0.154 \mathrm{~mol} / 1$ sodium chloride administered two minutes after the last epoprostenol infusion, and the coronary angiogram was repeated to give a fourth coded film.

\section{DRUG INFUSIONS}

The sodium salt of prostaglandin (epoprostenol, Wellcome Foundation) stored as a freeze dried powder was dissolved in glycine buffer $(\mathrm{pH} \mathrm{10.5)}$ to make a concentrated solution of $10000 \mathrm{ng} / \mathrm{ml}$. Immediately before infusion this was further diluted with glycine buffer to a concentration of $20 \mathrm{ng} / \mathrm{ml}$. The final dilutions were made with $0.154 \mathrm{~mol} / \mathrm{l}$ sodium chloride to a maximum ratio of six volumes of saline to one volume of epoprostenol to maintain an alkaline $\mathrm{pH}$.

The first two patients in the study were given low dose intracoronary infusions of epoprostenol (2.5 and $5.0 \mathrm{ng} / \mathrm{kg}$ per minute) to check safety. The next ten patients had infusions of 5.0 and $7.5 \mathrm{ng} / \mathrm{kg}$ per minute (group 1) and the final four patients had infusions of 7.5 and $10.0 \mathrm{ng} / \mathrm{kg}$ per minute (group 2). All patients, except the first two, had additional infusions of isosorbide dinitrate $(100 \mu \mathrm{g}$ in $20 \mathrm{ml} 0.154 \mathrm{~mol} / 1$ sodium chloride). One patient was also given an infusion of the buffer alone.

\section{MEASUREMENT OF THE DIAMETER OF THE LUMEN OF THE EPICARDIAL CORONARY ARTERIES}

Of the 16 patients studied, all but one had coronary artery disease. Seven patients had two vessel disease, six patients had three vessel disease, and two patients had single vessel disease. Only normal segments of coronary artery were chosen for measurement.

The angiographic recordings were coded and the code was not broken until all the film measurements had been made consecutively at the end of the study. The $35 \mathrm{~mm}$ cine films were viewed on a Tagarno projector, and the luminal diameter of the coronary artery was determined by tracing on to paper a chosen part of the vessel from end diastolic frames and measuring this directly with a calibrated eye glass (Flubacher, Switzerland). The catheter (of known diameter) was also traced from the same angiographic frame to provide a measure of magnification. All measurements were made by the same observer (JW). The method was similar to that used by Meier et al. ${ }^{6}$ We compared the coronary artery luminal diameters by Friedman's analysis of variance.

\section{Results}

LUMINAL DIAMETER OF THE CORONARY ARTERY The ten patients in group 1 had intracoronary epoprostenol infusions of 5.0 and $7.5 \mathrm{ng} / \mathrm{kg}$ per minute and no significant changes were seen in the luminal calibre. After infusion of isosorbide dinitrate, however, the calibre of the lumen increased by $11 \%$ compared with the control values $(p<0.02)$ (table). One patient in this group had an additional infusion of buffer solution alone, which did not change the luminal calibre (control $2.39 \mathrm{~mm}$,

Table Intraluminal diameter of epicardial coronary arteries after intracoronary infusion of epoprostenol (PGI $)$

\begin{tabular}{|c|c|c|c|c|}
\hline & \multicolumn{4}{|c|}{ Mean (SD) coronary artery diameter ( $\mathrm{mm}$ ) } \\
\hline & Control & 1st infusion & 2nd infusion & $\begin{array}{l}\text { Isosorbide } \\
\text { dinitrate }\end{array}$ \\
\hline $\begin{array}{l}\text { Group } 1 \\
\text { (10 patients) } \\
\text { Group } 2 \\
\text { (4 patients) }\end{array}$ & $\begin{array}{l}2.85(0.62) \\
3.50(0.45)\end{array}$ & $\begin{array}{l}2.80(0.61) \\
2.96(0.81)\end{array}$ & $\begin{array}{l}2.80(0.54) \\
3.45(0.96)\end{array}$ & $\begin{array}{l}3.17(0.36)^{\star} \\
3.20(0.61) \dagger\end{array}$ \\
\hline
\end{tabular}


(1)<smiles>C=C(C)NC(C)NC(C)C</smiles>

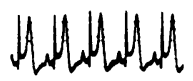
athathathell

(2)

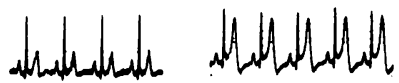
thuthuh ian
(3).

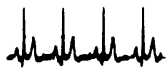

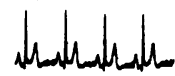

After

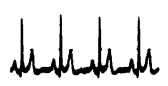

During

\section{Discussion}

The results indicate that intracoronary epoprostenol does not dilate the epicardial coronary arteries. The lack of response to epoprostenol was not caused by the inability of the diseased vessels to respond, because subsequent infusion of isosorbide dinitrate significantly increased the luminal diameter. The apparent failure to respond to isosorbide among patients in group 2 was misleading; it was the result of small numbers and the failure of one patient to respond, probably because of compensatory vasoconstriction after hypotension. The doses tolerated in this study were slightly higher than those routinely given in peripheral intravenous infusions ${ }^{7-9}$ but increasing the dose to $10 \mathrm{ng} / \mathrm{kg}$ per minute produced hypotension.

The study was carried out as a preliminary to investigating the use of epoprostenol given by intracoronary infusion during coronary artery angioplasty with the aim of promoting vasodilatation and inhibiting platelet function. Our results have shown that intracoronary epoprostenol does not increase the diameter of the epicardial coronary artery. Other investigators have shown an increase in coronary blood flow with intravenous epoprosteno ${ }^{8}$ and intracoronary prostaglandin $\mathrm{E}_{1},{ }^{10}$ probably caused by dilatation of the resistance vessels. Nitrates are customarily used during angioplasty to achieve maximal dilatation of the epicardial coronary artery, and it is unlikely that epoprostenol alone would achieve such an objective. Coronary artery dilatation might occur with higher doses of epoprostenol but the risk of inducing hypotension would be unacceptable (patient 3, group 2).

The inhibitory effect of epoprostenol on platelets has been seen with peripheral intravenous infusions, ${ }^{11}$ and this combined with the antithrombotic effect of increased coronary flow ${ }^{8}$ suggests that intracoronary administration is unlikely to have any added benefit.

Intracoronary infusions of epoprostenol were associated with $\mathrm{T}$ wave peaking and slight elevation of the ST segment. Although no arrhythmias were detected, these changes in the presence of "angioplasty induced ischaemia", are potentially hazardous. It seems that the electrocardiographic changes were directly related to the buffer, which is highly alkaline $(\mathrm{pH} \bumpeq 10.5)$ and which when infused on its own reproduced these changes. Eight of the patients who developed electrocardiographic changes had either two or three vessel coronary artery disease, and such ischaemic changes on the electrocardiogram might have been a consequence of a "steal" phenomenon, ${ }^{8}$ although this seems unlikely because the buffer alone also produced a similar effect. developed during epoprostenol infusion, which occurred with contrast and isosorbide infusion. Both of these patients had severe coronary artery disease. 
In conclusion, intracoronary infusion of epoprostenol is unlikely to confer any additional benefit over the effects of intravenous administration during angioplasty procedures. The data indicate that epoprostenol at tolerable doses cannot be used instead of nitrates for dilatation of the epicardial arteries. Any antithrombotic actions of the drug, which might help to reduce the incidence of restenosis associated with angioplasty, are just as likely to be achieved by peripheral intravenous infusion.

We thank the Wellcome Foundation for supplying the epoprostenol and for their financial support.

\section{References}

1 Moncada S, Gryglewski RJ, Bunting S, Vane JR. An enzyme isolated from arteries transforms prostaglandin endoperoxide to an unstable substance that inhibits platelet aggregation. Nature 1976;263: 663-5.

2 Prentice CRM, Belch JJF, McKay A, et al. Prostacyclin and severe peripheral arterial disease: $a$ double blind trial [Abstract]. Thromb Haemost 1983;50:335.

3 Rubin LJ, Graves BM, Reaves JT, Frosolano M, Handel F, Cata AE. Prostacyclin induced acute pulmonary vasodilation in pulmonary hypertension. Circulation 1982;66:334-8.
4 Hintze TH, Kichuk MR, Stern H, Kaley G. Dilation of large coronary arteries in conscious dogs by prostacyclin. In: Neri Serneri GG, McGiff JC, Paoletti R, Born GVR, eds. Advances in prostaglandin, thromboxane and leukotriene research, vol 13. New York: Raven Press, 1985:43-6.

5 Hall RJC, Dewar HA. Safety of coronary arterial prostacyclin infusion. Lancet 1981;i:949.

6 Meier B, Gruentzig AR, Goebel N, Pyle R, von Gossler W, Schlumpf M. Assessment of stenoses in coronary angioplasty. Inter- and intra-observer variability. Int J Cardiol 1983;3:159-69.

7 Kiernan FJ, Kluger J, Regnier JC, Rutkowski M, Fieldman A. Epoprostenol sodium (prostacyclin) infusion in acute myocardial infarction. Br Heart $\mathrm{J}$ 1986;56:428-32.

8 Bugiardini R, Galvani M, Ferrini D, et al. Myocardial ischaemia during intravenous prostacyclin administration. Haemodynamic findings and precautionary measures. Am Heart J 1986;113:234-40.

9 Henriksson P, Edhag O, Wennmalm A. Prostacyclin infusion in patients with acute myocardial infarction. Br Heart J 1985;53:173-9.

10 See JR, Lieber IH, Mathews DO, Shell WE. Effect of intracoronary PGE-1 on myocardial blood flow pre and post coronary angiography in man [Abstract]. Circulation 1985;72(suppl III):370.

11 Gryglewski RJ, Szceklik A, Nizankowski R. Antiplatelet action of intravenous infusion of prostacyclin in man. Thromb Res 1978;13:153-63. 